\title{
Protection against heartwater by DNA immunisation with four Ehrlichia ruminantium open reading frames
}

\author{
A. Pretorius $^{a, b}$, N.E. Collins ${ }^{b}$, H.C. Steyn ${ }^{a}$, F. van Strijp ${ }^{a}$, M. van Kleef and \\ B.A. Allsopp ${ }^{\text {b }}$
}

${ }^{a}$ Onderstepoort Veterinary Institute, Private Bag X5, Onderstepoort 0110, South Africa

${ }^{b}$ Department of Veterinary Tropical Diseases, University of Pretoria, Private Bag X04, Onderstepoort 0110, South Africa

\begin{abstract}
We have reported previously that a recombinant DNA vaccine consisting of four Ehrlichia ruminantium (Welgevonden) open reading frames (ORFs) known as the 1H12 cocktail provided protection against a virulent E. ruminantium (Welgevonden) needle challenge in sheep. In this study, we have investigated the vaccine effectiveness of two other cocktails of E. ruminantium (Welgevonden) ORFs, as well as single ORFs from the $1 \mathrm{H} 12$ cocktail, to protect sheep against a virulent needle challenge with the homologous strain. Each individual 1H12 ORF provided protection, but all the animals vaccinated with the other cocktails succumbed to the challenge.
\end{abstract}

\section{Article Outline}

1. Introduction

2. Materials and methods

2.1. Cloning of ORFs into pCMViUBs vector

2.2. Immunisation of sheep with the DNA vaccines

2.2.1. DNA vaccine trial 1: comparison of the $1 \mathrm{H} 12$ DNA vaccine with two other $E$. ruminantium (Welgevonden)-derived vaccine cocktails 
2.2.2. DNA vaccine trial 2: immunisation with the $1 \mathrm{H} 12$ cocktail compared to inoculation with the individual $1 \mathrm{H} 12 \mathrm{ORFs}$

2.3. Lymphocyte proliferation assays

2.4. Identification of $\mathrm{CpG}$ islands

2.5. Statistical analysis

3. Results

3.1. Identification of $\mathrm{CpG}$ islands

3.2. DNA immunisation of sheep with the $1 \mathrm{H} 12$ cocktail compared to immunisation with WL2AP1 and WL2HCS1 cocktails

3.3. Immunisation of animals with individual 1H12 ORFs

3.4. Immunological assays of sheep immunised with individual ORFs compared to the $1 \mathrm{H} 12$ cocktail.

4. Discussion

Acknowledgements

References

\section{Introduction}

Ehrlichia ruminantium, a rickettsial agent transmitted to wild and domestic ruminants by Amblyomma tick species, is the causative agent of the disease known as heartwater which is prevalent in sub-Saharan Africa and the Caribbean [1] and [2]. In South Africa, heartwater is controlled either by acaricides to prevent tick transmission or by using a method known as infection and treatment [3]. The blood of donor animals infected with the Ball3 isolate is used to infect susceptible livestock and when a temperature response is detected the animals are treated with tetracycline. This vaccination procedure is fairly successful in the field, but is laborious, as each animal's temperature must be closely monitored. The isolate used (Ball3) is also not ideal because it does not completely crossprotect against all the various field genotypes of E. ruminantium [4]. The use of more virulent isolates which may provide better cross-protection is not feasible, as the onset of symptoms is faster than with Ball3 and in many cases once fever is detected it is too late to treat. The distribution of the vaccine also presents a problem in rural areas because the delivery relies on an uninterrupted cold chain. There is therefore a need for an improved 
vaccine against heartwater. Several attempts which have been made to improve on the current vaccine include the development of inactivated vaccines [5], [6], [7], [8] and [9], attenuated vaccines [10] and [11] and major antigenic protein 1 (MAP1) DNA vaccines [12] and [13].

We have previously reported the identification of 11 open reading frames (ORFs) in a cosmid clone containing an E. ruminantium DNA fragment [14] known as 1H12. Four of these ORFs (Erum2540, Erum2550, Erum2580 and Erum2590, Table 1) were shown to induce partial protection in mice and $100 \%$ protection in sheep against homologous needle challenge when inoculated as a cocktail using a DNA vaccination strategy [4] and [15]. In this study, we have further investigated the immunity stimulated in sheep by $E$. ruminantium ORFs, presented as a DNA vaccine, and their ability to induce protective immunity against a lethal heartwater needle challenge. We tested the $1 \mathrm{H} 12$ cocktail as before, and compared the results with those obtained when using each ORF individually. As an immunological control, we also tested two other cocktails composed of ORFs randomly selected from large inserts that were sequenced previously [16]. Table 1.

ORFs used for the three vaccine cocktails (1H12, WL2AP1 and WL2HCS1) selected from the E. ruminantium (Welgevonden) fragments sequenced previously

\begin{tabular}{|l|l|l|l|l|}
\hline Cocktail & Number $^{\mathbf{a}}$ & Closest homologies & $\begin{array}{l}\text { (\%) GC } \\
\text { content }^{\mathbf{b}}\end{array}$ & $\begin{array}{l}\text { Number of putative } \\
\text { CpG islands } \\
\text { predicted by }^{\text {EMBOSS: cpgplot }}\end{array}$ \\
\hline $1 \mathrm{H} 12$ & Erum2540 & Exported protein & 30.11 & 1 \\
\hline & Erum2550 & $\begin{array}{l}\text { ATP-binding protein part } \\
\text { of ABC transporters }\end{array}$ & 31.28 & 2 \\
\hline & Erum2580 & $\begin{array}{l}\text { Periplasmic solute binding } \\
\text { protein (SBP) }\end{array}$ & 26.04 & 1 \\
\hline & Erum2590 & ATP-binding protein part & 26.88 & 1 \\
\hline
\end{tabular}




\begin{tabular}{|c|c|c|c|c|}
\hline Cocktail & Number $^{\mathrm{a}}$ & Closest homologies & $\begin{array}{l}(\%) \mathrm{GC} \\
\text { content }^{\mathbf{b}}\end{array}$ & $\begin{array}{l}\text { Number of putative } \\
\text { CpG islands } \\
\text { predicted by } \\
\text { EMBOSS: cpgplot }\end{array}$ \\
\hline & & of $\mathrm{ABC}$ transporters & & \\
\hline \multirow[t]{4}{*}{ WL2AP1 } & Erum7450 & $\begin{array}{l}\text { Probable integral } \\
\text { membrane protein }\end{array}$ & 30.89 & 3 \\
\hline & Erum7490 & $\begin{array}{l}\text { Probable inorganic } \\
\text { polyphosphate/ATP-NAD } \\
\text { kinase }\end{array}$ & 31.06 & 1 \\
\hline & Erum7510 & Hypothetical protein & 28.13 & 1 \\
\hline & Erum7530 & $\begin{array}{l}\text { Putative conjugal transfer } \\
\text { protein }\end{array}$ & 31.78 & 2 \\
\hline \multirow[t]{3}{*}{ WL2HCS1 } & Erum6480 & Probable peptidase & 30.08 & None \\
\hline & Erum6490 & Hypothetical protein & 31.14 & None \\
\hline & Erum6530 & Hypothetical protein & 30.64 & None \\
\hline
\end{tabular}

${ }^{a}$ Erum numbers are taken from Collins et al. [39].

${ }^{\mathrm{b}}$ Determined from the annotated genome sequence.

\section{Materials and methods}

\subsection{Cloning of ORFs into $\mathrm{pCMViUBs}$ vector}

ORFs were selected from cosmid clone 1H12 [14] and from two LambdaGEM-11 clones designated WL2AP1 and WL2HCS1 (Table 1), sequenced previously [16]. The ORFs 
were amplified from E. ruminantium genomic DNA and the PCR products were cloned into the DNA vaccine vector pCMViUBs [17] as described previously [4] and [15].

Briefly, the PCR, using ORF-specific primers that contained restriction enzyme sites to facilitate directional cloning (Table 2), was performed using TaKaRa Ex Taq ${ }^{\mathrm{TM}}$ (TaKaRa Bio Inc.) in a GeneAmp PCR 9700 thermocycler (Applied Biosystems). The PCR products were first cloned into pMOSBlue (Amersham Pharmacia Biotech) according to the manufacturer's instructions, and their sequences were confirmed. The inserts were then cut out of the pMOSBlue_ORF plasmids using the restriction enzyme sites incorporated into the primer sequences and were cloned into the pCMViUBs vector [17] using T4 DNA ligase. Clones with correctly sized inserts were sequenced to confirm that the ORFs were in-frame.

Table 2.

Primer sequences of ORFs used for cloning into the pCMViUBs vector

\begin{tabular}{|c|c|c|c|}
\hline Clone & Primer & Primer sequence $\left(5^{\prime} \rightarrow 3^{\prime}\right)^{a}$ & $T_{\mathrm{a}}\left({ }^{\circ} \mathrm{C}\right)^{\mathrm{b}}$ \\
\hline \multirow[t]{7}{*}{$\begin{array}{l}\text { WL2AP } \\
1\end{array}$} & Erum7450 F & CGCGGATCCATGGAGGTTATTTTGAGTAGG & \\
\hline & Erum7450 R & $\begin{array}{l}\text { GATCTCTAGATTAGTTTACATACTTTTTATTTTTAT } \\
\text { ATTTTTAG }\end{array}$ & 58 \\
\hline & Erum7490 F & CGCGGATCCATGAGCAATTATCAAAACATTGGG & \\
\hline & Erum7490 R & 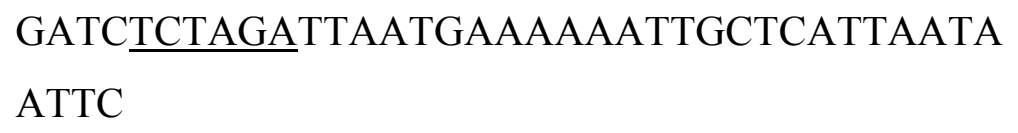 & 52 \\
\hline & Erum7510 F & $\begin{array}{l}\text { CGCGGATCCATGCTATTTCATACATTAGATATAAA } \\
\text { TC }\end{array}$ & \\
\hline & Erum7510 R & $\begin{array}{l}\text { GATCTCTAGATTATGTTAGTAACCAGTTTTGTATA } \\
\text { TC }\end{array}$ & 52 \\
\hline & Erum $7530 \mathrm{~F}$ & CGCGGATCCATGAAAAATTTAGTAGTAG & \\
\hline
\end{tabular}


openUP (July 2007)

\begin{tabular}{|c|c|c|c|}
\hline \multirow[t]{2}{*}{ Clone } & Primer & Primer sequence $\left(5^{\prime} \rightarrow 3^{\prime}\right)^{\mathrm{a}}$ & $T_{\mathrm{a}}\left({ }^{\circ} \mathrm{C}\right)^{\mathrm{b}}$ \\
\hline & Erum7530 R & GATCTCTAGACTAGCGTTTCTTTTTATTG & 45 \\
\hline \multirow[t]{6}{*}{$\begin{array}{l}\text { WL2H } \\
\text { CS }\end{array}$} & Erum6480 F & CGCGGATCCATGTTCTTATGTTTTGGTTG & \\
\hline & Erum6480 R & CTAGTCTAGATTATTCTAATGATTTAG & 43 \\
\hline & Erum6490 F & CGCGGATCCATGCCAGAATATGTATCAG & \\
\hline & Erum6490 R & CTAGTCTAGATTAATAGTATATTCTTCCAC & 48 \\
\hline & Erum6530 F & CGCGGATCCATGATTGATGCACAAACTCG & \\
\hline & Erum6530 R & CTAGTCTAGATTATTTTTTATCACAAAATGC & 50 \\
\hline
\end{tabular}

${ }^{\text {a }}$ Restriction enzyme sites incorporated into the primers to facilitate directional cloning are underlined.

${ }^{\mathrm{b}}$ Annealing temperature $\left(T_{\mathrm{a}}\right)$ used for primer pair.

Large-scale plasmid isolation was performed using the Nucleobond PC 2000 kit, according to the instructions of the manufacturer. The plasmid DNA was diluted in endotoxin-free PBS to a final concentration of $1 \mathrm{mg} / \mathrm{ml}$ and stored at $-20^{\circ} \mathrm{C}$. A sample of each plasmid containing an E. ruminantium ORF was sequenced prior to immunisation.

\subsection{Immunisation of sheep with the DNA vaccines}

Six to eight month old Merino sheep were obtained from heartwater-free areas of South Africa. All sheep used in these experiments tested negative for E. ruminantium using the pCS20 probe [18]. Sheep were divided into groups of 5 and each animal received DNA via intramuscular (i.m.) inoculations into the left and right quadriceps and tibialis anterior muscles and via intradermal i.d. gene gun delivery of the same DNA. Gene gun inoculation was delivered to the lateral aspect of the pinna using the OPgun ${ }^{\mathrm{TM}}$ [19]. Before inoculation, the ear surface was depilated with Immac $^{\mathrm{TM}}$ to remove hair and dead skin, and the DNA was freshly precipitated onto gold beads as described previously [19]. 
The animals were immunised three times at 3-week intervals and challenged 5 weeks after the final boost with the virulent E. ruminantium (Welgevonden) stock $\left(10 \mathrm{LD}_{50}\right)$ originating in South Africa [20]. Blood stabilate was prepared from an E. ruminantium (Welgevonden) infected animal as described previously [21]. The infected sheep blood was diluted in sucrose potassium glutamate buffer (SPG) $(0.22 \mathrm{M}$ sucrose, $0.01 \mathrm{M}$ potassium phosphate $\mathrm{pH} 7.0,5 \mathrm{mM}$ potassium glutamate) and stored in liquid nitrogen. The stabilate was titred to determine a dose equivalent to $10 \mathrm{LD}_{50}$ prior to challenge. The animals were monitored for onset of clinical symptoms after challenge and rectal temperatures were taken daily from the start of the experiment. The severity of infection was determined by scoring the clinical signs according to a reaction index (RI) [4] with some modifications: animals that were treated were regarded as non-survivors and were therefore given a score identical to that of animals that were euthanased (Table 3). It was also decided to increase the previous score of 20 [4] for animals that were euthanased to 50 in order to differentiate more clearly between animals that succumbed to the infection and animals that survived but had a fever reaction for up to 6 days. In trial 1 sheep were euthanased in extremis using $200 \mathrm{mg}$ sodium pentobarbitone (Eutha-Nase, Centaur) per $\mathrm{kg}$ body mass. In all subsequent animal trials it was decided to treat sheep with $200 \mathrm{mg}$ oxytetracycline (Liquamycin/LA, Pfizer) per $10 \mathrm{~kg}$ body mass once elevated temperatures were detected combined with severe heartwater symptoms that included hyperesthesia, lacrimation and convulsions.

Table 3.

Reaction index for sheep challenged with E. ruminantium (Modified from Collins et al. [4])

\section{Indicator}

1. Before challenge

Record temp for each sheep for 10 days prior to challenge

Determine average temperature for each sheep

2. After challenge

Temperature 


\begin{tabular}{|l|l|}
\hline Indicator & Score \\
\hline For every $1^{\circ} \mathrm{C}$ above the average temp & \\
\hline & \\
\hline Symptoms & +5 \\
\hline $\begin{array}{l}\text { Loss of appetite, heavy breathing, hanging head, stiff gait, depression, } \\
\text { exaggerated blinking and chewing movements with anorexia }\end{array}$ & +10 \\
\hline $\begin{array}{l}\text { Hyperesthesia, lacrimation, convulsions, nervous symptoms, animal cannot } \\
\text { stand on its own }\end{array}$ & \\
\hline & +50 \\
\hline Treatment & +50 \\
\hline i.m. or i.v. treatment & \\
\hline & \\
\hline Death/euthanasia & \\
\hline Body tompatians & \\
\hline
\end{tabular}

Body temperatures and symptoms were monitored for the duration of the experiment. After challenge, animals were scored daily according to their temperature reaction, symptoms displayed and treatment received. Scores were totalled throughout the duration of the experiment.

\subsubsection{DNA vaccine trial 1: comparison of the $1 \mathrm{H} 12$ DNA vaccine with two other $E$. ruminantium (Welgevonden)-derived vaccine cocktails}

The survival of sheep inoculated with the $1 \mathrm{H} 12$ cocktail was compared to that of two other cocktails composed of $E$. ruminantium ORFs selected from previously sequenced E. ruminantium (Welgevonden) genome fragments WL2AP1 and WL2HCS1 [16]. A total of 7 ORFs were selected: 3 from WL2HCS1 and 4 from WL2AP1 (Table 1). The groups inoculated with the $1 \mathrm{H} 12$ cocktail and WL2AP1 received a total of $200 \mu \mathrm{g}$ of DNA via i.m. inoculation comprising a mixture of the four ORFs (50 $\mu \mathrm{g}$ each) and also received $20 \mu \mathrm{g}$ of DNA via gene gun inoculation (five shots of each ORF containing $1 \mu \mathrm{g}$ DNA per shot). The third group of animals was inoculated with the WL2HCS1 cocktail and received $200 \mu \mathrm{g}$ DNA via i.m. inoculation (66.6 $\mu \mathrm{g}$ of each ORF) and $21 \mu \mathrm{g}$ of DNA ( $7 \mu \mathrm{g}$ per ORF) via gene gun inoculation. The survival of these three groups was 
compared to a negative challenge control group (naive, non-immunised animals), a positive challenge control group immunised using the conventional infection and treatment method using the Welgevonden isolate, and a negative DNA control group (inoculated with empty pCMViUBs vector $200 \mu \mathrm{g}$ i.m. and $20 \mu \mathrm{g}$ i.d.).

\subsubsection{DNA vaccine trial 2: immunisation with the $1 \mathrm{H12}$ cocktail compared to inoculation with the individual 1 H12 ORFs}

Five experimental groups were inoculated as follows: Group 1 was immunised with the $1 \mathrm{H} 12$ cocktail as described in Section 2.2.1. The remaining four groups were each inoculated with one of the four 1H12 ORFs. Each animal inoculated with a single ORF received a total of $200 \mu \mathrm{g}$ of the ORF-plasmid DNA i.m. and $20 \mu \mathrm{g}$ via gene gun inoculation. The survival of these groups was compared to a negative challenge control, positive challenge control, and negative DNA control groups, as described above.

\subsection{Lymphocyte proliferation assays}

Peripheral blood mononuclear cell (PBMC) lymphocyte proliferation assays were performed before immunisation, and 4 weeks after the third inoculation, as described previously [22]. Briefly, a single cell suspension was prepared in RPMI 1640 medium supplemented with $10 \%$ heat-inactivated FCS, $2 \mathrm{mM}$ 1-glutamine (Sigma), $5 \times 10^{-5} \mathrm{M} 2$ mercaptoethanol (Sigma), $0.1 \mathrm{mg} / \mathrm{ml}$ sodium benzyl penicillin (Novopen, Nova Nordisk) and $0.2 \mathrm{mg} / \mathrm{ml}$ streptomycin sulphate (Novostrep, Nova Nordisk). Proliferation assays were carried out in triplicate in half-area $96-$ well plates (Costar) at $37^{\circ} \mathrm{C}$ in a humidified atmosphere supplemented with $5 \% \mathrm{CO}_{2}$. In a total volume of $100 \mu \mathrm{l}$, $2 \times 10^{5} \mathrm{PBMCs} /$ well were incubated with partially purified E. ruminantium antigen isolated from infected bovine endothelial cells ( $1 \mu \mathrm{g} /$ well, positive antigen) or with uninfected bovine endothelial cell extract ( $1 \mu \mathrm{g} / \mathrm{well}$, negative antigen). The $E$. ruminantium antigen was prepared by differential centrifugation as described previously [22]. Negative control wells contained PBMC without antigen and positive control wells contained PBMCs stimulated with Concanavalin A ( $5 \mu \mathrm{g} / \mathrm{ml}$, Sigma). The cultures were incubated for $72 \mathrm{~h}$ and pulsed with $1 \mu \mathrm{Ci} /$ well of $\left[{ }^{3} \mathrm{H}\right]$ thymidine (Amersham) for the last $6 \mathrm{~h}$ of the incubation period. Cells were harvested onto a 96-well glass fibre filter 
(Wallac) and the $\left[{ }^{3} \mathrm{H}\right]$ thymidine uptake was counted after addition of $5 \mathrm{ml}$ scintillation solution (Ultima gold F, Packard BioScience) using a Trilux 1450 Microbeta liquid scintillation counter (Wallac).

Results were expressed as Stimulation Index (SI) (counts per minute (cpm) of positive antigen divided by cpm of negative antigen) averaged from triplicate wells \pm the standard deviation. A SI greater than 2 was considered positive.

\subsection{Identification of $\mathrm{CpG}$ islands}

CpG islands were identified in the E. ruminantium derived ORFs by using EMBOSS: cpgplot (http://www.ebi.ac.uk/emboss/cpgplot). A putative $\mathrm{CpG}$ island was defined as a region where the $\mathrm{GC}$ content was over $30 \%$, the calculated observed/expected ratio was over 0.6 and the conditions spanned a minimum of 50 bases.

\subsection{Statistical analysis}

RI scores and lymphocyte proliferation results were compared by means of the Student's $t$-test. Significance was assessed at $p$-values of $\leq 0.01$ throughout the study.

\section{Results}

\subsection{Identification of $\mathrm{CpG}$ islands}

All 11 ORFs had a low GC content ranging from 26.04 to 31.78\% (Table 1). Putative $\mathrm{CpG}$ islands with a minimum of $30 \% \mathrm{GC}$ content were identified in the $1 \mathrm{H} 12$ and the WL2AP1 ORFs; the putative CpG islands in these ORFs were similar in number and size. No CpG islands were found in the WL2HCS1 ORFs (Table 1).

\subsection{DNA immunisation of sheep with the $1 \mathrm{H} 12$ cocktail compared to immunisation with WL2AP1 and WL2HCS1 cocktails}

Sheep immunised with the $1 \mathrm{H} 12$ cocktail survived needle challenge with a lethal dose of E. ruminantium (Welgevonden) (Fig. 1; Table 4). The sheep in this group showed increased RI values (the average RI value for this group was 35.8; Fig. 1) compared to the RI of the infected and treated group (an average RI score of 1; Fig. 1). This was due to temperature reactions and mild heartwater symptoms including heavy breathing and a 
hanging head (as observed in our previous study [4] and [15]), but all the animals continued to act and eat normally. In contrast, the challenge control sheep, the animals inoculated with empty vector (negative control group) and the animals immunised with the WL2AP1 and WL2HCS1 ORF cocktails, all developed severe symptoms including hyperesthesia, lacrimation and convulsions and were euthanased to prevent prolonged suffering. The RI scores of the sheep immunised with the $1 \mathrm{H} 12$ cocktail were significantly lower than those of the empty vector group $(p \leq 0.0006)$ and those of the sheep immunised with the WL2AP1 cocktail $(p \leq 0.00006)$ and the WL2HCS1 cocktail $(p \leq 0.00003$ ) (Fig. 1). Furthermore the RI of animals immunised with the WL2AP1 and WL2HCS1 ORF cocktails showed no significant difference ( $p \leq 0.0474$ for WL2AP1 and $p \leq 0.0220$ for WL2HCS1) to the reaction indices of the negative control group immunised with empty vector (Fig. 1). However some of the animals did survive 1-4 days longer than the negative control group (Table 4) and therefore had average RI scores that were higher than that of the negative control group (Fig. 1). Sheep that were infected and treated had very low RI scores because they did not show any symptoms and only developed slight temperature reactions.

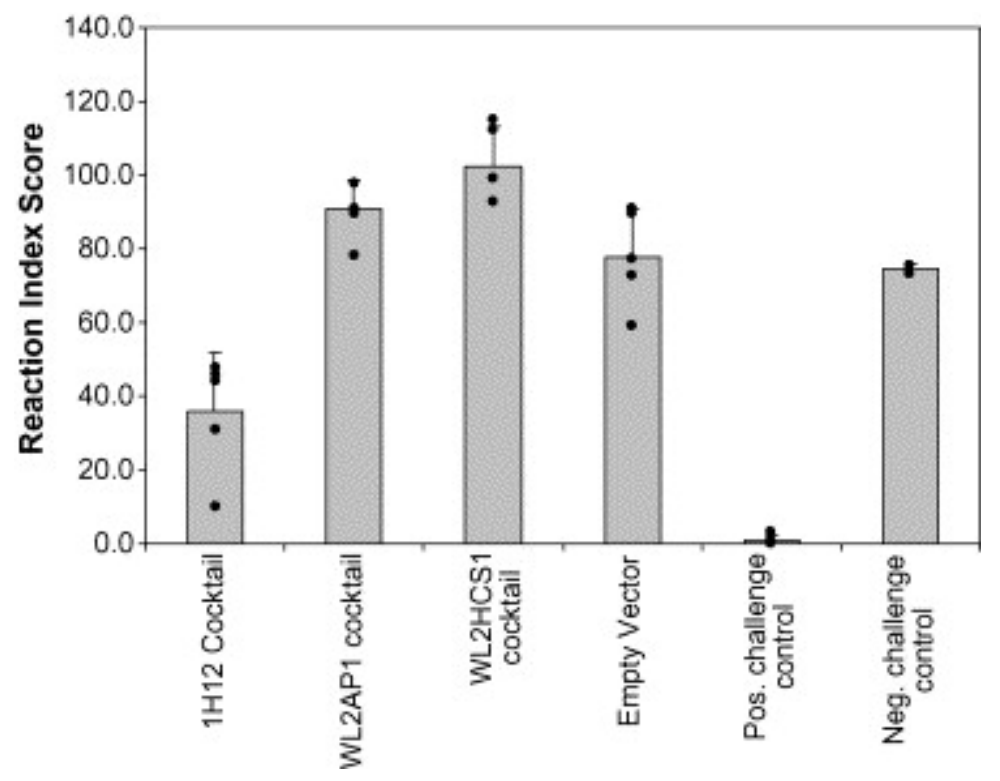

Fig. 1. The average RI of animals immunised with the $1 \mathrm{H} 12$ cocktail compared to animals immunised with two other E. ruminantium (Welgevonden) cocktails: WL2AP1 and WL2HCS1 (Table 2). The black dots represent the RI of each animal in the group. 
Table 4.

The survival of sheep immunised with the $1 \mathrm{H} 12$ cocktail compared to that of sheep immunised with WL2AP1 and WL2HCS1 cocktails and animals immunised with empty pCMViUBs vector

\begin{tabular}{|c|c|c|c|c|}
\hline Group & $\begin{array}{l}\text { Sheep } \\
\text { number }\end{array}$ & $\begin{array}{l}\text { Days to } \\
\text { temperature } \\
\text { above } 40{ }^{\circ} \mathrm{C}\end{array}$ & $\begin{array}{l}\text { Highest } \\
\text { temperature } \\
\text { reached }\left({ }^{\circ} \mathrm{C}\right)\end{array}$ & $\begin{array}{l}\text { Survival (S) or } \\
\text { euthanased (E) on } \\
\text { (day) shown }\end{array}$ \\
\hline \multirow[t]{5}{*}{$\begin{array}{l}\text { Empty } \\
\text { vector }\end{array}$} & 551 & 14 & 41.6 & E (15) \\
\hline & 552 & 12 & 42 & E (15) \\
\hline & 553 & 12 & 42 & E (15) \\
\hline & 556 & 13 & 42 & E (15) \\
\hline & 559 & 14 & 42 & E (15) \\
\hline \multirow{5}{*}{$\begin{array}{l}1 \mathrm{H} 12 \\
\text { cocktail }\end{array}$} & 462 & 13 & 41.2 & $\mathrm{~S}$ \\
\hline & 465 & 14 & 41.8 & S \\
\hline & 476 & 14 & 41.8 & S \\
\hline & 484 & - & 39.9 & S \\
\hline & 488 & 12 & 42 & S \\
\hline \multirow[t]{5}{*}{ WL2AP1 } & 503 & 12 & 42 & E (16) \\
\hline & 506 & 12 & 41.9 & E (16) \\
\hline & 512 & 12 & 42 & E (17) \\
\hline & 514 & 12 & 42 & E (16) \\
\hline & 515 & 12 & 42 & E (17) \\
\hline WL2HCS1 & 516 & 11 & 42 & E (15) \\
\hline
\end{tabular}




\begin{tabular}{|l|l|l|l|l|}
\hline Group & $\begin{array}{l}\text { Sheep } \\
\text { number }\end{array}$ & $\begin{array}{l}\text { Days to } \\
\text { temperature } \\
\text { above } \mathbf{4 0}^{\circ} \mathbf{C}\end{array}$ & $\begin{array}{l}\text { Highest } \\
\text { temperature } \\
\text { reached }\left({ }^{\circ} \mathbf{C}\right)\end{array}$ & $\begin{array}{l}\text { Survival (S) or } \\
\text { euthanased (E) on } \\
\text { (day) shown }\end{array}$ \\
\hline & 519 & 12 & 42 & E (15) \\
\hline & 525 & 12 & 41.8 & E (15) \\
\hline & 531 & 11 & 42 & E (17) \\
\hline & 532 & 12 & 42 & E (19) \\
\hline
\end{tabular}

\subsection{Immunisation of animals with individual $1 \mathrm{H} 12$ ORFs}

Animals were immunised with each $1 \mathrm{H} 12 \mathrm{ORF}$ to determine if one or all of the individual ORFs were responsible for the protection induced by the cocktail. All the sheep immunised with the single $1 \mathrm{H} 12$ ORFs survived a virulent E. ruminantium (Welgevonden) needle challenge (Table 5). Only animals immunised with the empty vector developed severe heartwater symptoms and were treated (Fig. 2). Animals immunised with the cocktail and single ORFs showed a similar increase in their RI scores (compared to the infected and treated group) as previously seen. Again this was due to the development of temperature reactions and early heartwater symptoms, but the animals continued to eat and act normally and survived without treatment (Table 5; Fig. 2).

Overall the RI scores of the groups immunised with the individual ORFs were significantly lower $(p \leq 0.003)$ than those of the negative control group, while no significant difference was observed between the RI scores of sheep immunised with the single ORFs as compared to the $1 \mathrm{H} 12$ cocktail group (Fig. 2). 


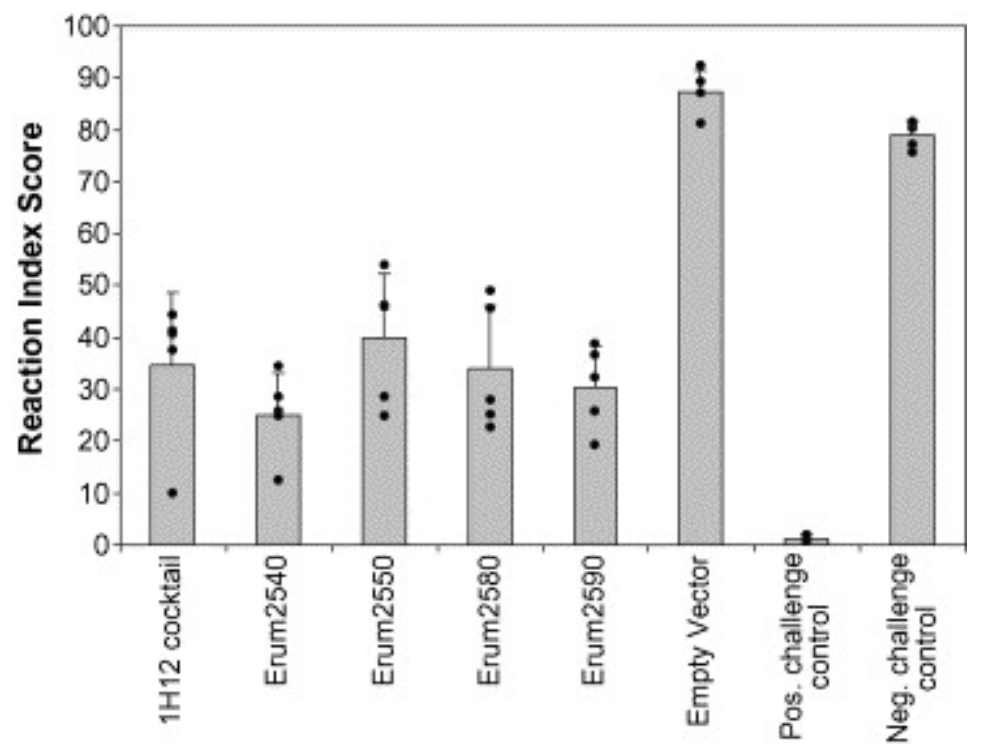

Fig. 2. The average RI of animals immunised with the $1 \mathrm{H} 12$ cocktail compared to animals immunised with the individual 1H12 ORFs: Erum2540, Erum2550, Erum2580 and Erum2590 (Table 2). The black dots represent the RI of each animal in the group. Table 5.

Survival and lymphocyte proliferation data of sheep inoculated with the single $1 \mathrm{H} 12$ ORFs compared to the $1 \mathrm{H} 12$ cocktail

\begin{tabular}{|c|c|c|c|c|c|c|}
\hline Group & $\begin{array}{l}\text { Sheep } \\
\text { num- } \\
\text { ber }\end{array}$ & $\begin{array}{l}\text { Days to } \\
\text { temperatu } \\
\text { re above } \\
40^{\circ} \mathrm{C}\end{array}$ & $\begin{array}{l}\text { Highest } \\
\text { temperature } \\
\text { reached }\left({ }^{\circ} \mathrm{C}\right)\end{array}$ & $\begin{array}{l}\text { Survival } \\
\text { (S) or } \\
\text { Treated } \\
\text { (T) on } \\
\text { (day) }\end{array}$ & $\begin{array}{l}\text { SI }^{\mathrm{a}} \text { (SI after } \\
\text { boost/SI naïve) }\end{array}$ & $\begin{array}{l}\text { Significance of } \\
S^{b}{ }^{b}(P \text { values) }\end{array}$ \\
\hline \multirow[t]{5}{*}{$\begin{array}{l}\text { Empty } \\
\text { vector }\end{array}$} & 46 & 10 & 41.9 & $\mathrm{~T}(12)$ & $1.09 \pm 0.05$ & \\
\hline & 52 & 10 & 42.0 & $\mathrm{~T}(13)$ & $1.22 \pm 0.39$ & \\
\hline & 55 & 10 & 42.0 & $\mathrm{~T}(13)$ & $0.93 \pm 0.16$ & \\
\hline & 57 & 10 & 41.8 & $\mathrm{~T}(13)$ & $0.88 \pm 0.25$ & \\
\hline & 61 & 10 & 42.0 & $\mathrm{~T}(13)$ & $1.16 \pm 0.15$ & \\
\hline $\begin{array}{l}\text { H12 } \\
\text { cocktail }\end{array}$ & 62 & 10 & 41.8 & $\mathrm{~S}$ & $2.62 \pm 0.17$ & Yes $(\leq 0.002)$ \\
\hline
\end{tabular}




\begin{tabular}{|c|c|c|c|c|c|c|}
\hline Group & $\begin{array}{l}\text { Sheep } \\
\text { num- } \\
\text { ber }\end{array}$ & $\begin{array}{l}\text { Days to } \\
\text { temperatu } \\
\text { re above } \\
40^{\circ} \mathrm{C}\end{array}$ & $\begin{array}{l}\text { Highest } \\
\text { temperature } \\
\text { reached }\left({ }^{\circ} \mathrm{C}\right)\end{array}$ & $\begin{array}{l}\text { Survival } \\
\text { (S) or } \\
\text { Treated } \\
\text { (T) on } \\
\text { (day) }\end{array}$ & $\begin{array}{l}\mathrm{SI}^{\mathrm{a}} \text { (SI after } \\
\text { boost/SI naïve) }\end{array}$ & $\begin{array}{l}\text { Significance of } \\
\text { SI }^{\mathbf{b}}(P \text { values })\end{array}$ \\
\hline & 73 & 10 & 41.8 & S & $0.61 \pm 0.16$ & No \\
\hline & 94 & 11 & 41.8 & S & $1.58 \pm 0.12$ & No \\
\hline & 96 & 11 & 41.7 & S & $1.24 \pm 0.43$ & No \\
\hline & 120 & 12 & 41.0 & S & $3.89 \pm 0.09$ & Yes $(\leq 0.006)$ \\
\hline & 129 & 11 & 42.0 & S & $1.60 \pm 0.31$ & No \\
\hline \multirow[t]{4}{*}{ Erum2550 } & 130 & 8 & 41.8 & S & $2.34 \pm 0.64$ & Yes $(\leq 0.001)$ \\
\hline & 143 & 10 & 41.8 & S & $2.55 \pm 0.58$ & Yes $(\leq 0.002)$ \\
\hline & 149 & 9 & 41.6 & S & $1.47 \pm 0.02$ & No \\
\hline & 151 & 10 & 41.6 & S & $2.10 \pm 0.06$ & $\begin{array}{l}\text { Yes } \\
(\leq 0.00003)\end{array}$ \\
\hline \multirow[t]{5}{*}{ Erum2590 } & 152 & 11 & 41.8 & S & $1.38 \pm 0.18$ & No \\
\hline & 166 & 12 & 41.5 & S & $0.9 \pm 0.15$ & No \\
\hline & 172 & 11 & 41.4 & S & $0.93 \pm 0.08$ & No \\
\hline & 183 & 11 & 41.8 & S & $2.51 \pm 0.41$ & Yes $(\leq 0.01)$ \\
\hline & 184 & 11 & 41.8 & S & $2.69 \pm 0.77$ & $\begin{array}{l}\text { Yes } \\
(\leq 0.00003)\end{array}$ \\
\hline \multirow[t]{5}{*}{ Erum2540 } & 196 & 9 & 41.6 & S & $0.97 \pm 0.25$ & No \\
\hline & 198 & 10 & 41.6 & S & $1.77 \pm 0.09$ & No \\
\hline & 202 & 11 & 41.7 & S & $1.30 \pm 0.10$ & No \\
\hline & 205 & 12 & 41.7 & S & $1.55 \pm 0.37$ & No \\
\hline & 206 & 11 & 41.7 & S & $7.34 \pm 0.6$ & Yes $(\leq 0.007)$ \\
\hline
\end{tabular}




\begin{tabular}{|c|c|c|c|c|c|c|}
\hline Group & $\begin{array}{l}\text { Sheep } \\
\text { num- } \\
\text { ber }\end{array}$ & $\begin{array}{l}\text { Days to } \\
\text { temperatu } \\
\text { re above } \\
40^{\circ} \mathrm{C}\end{array}$ & $\begin{array}{l}\text { Highest } \\
\text { temperature } \\
\text { reached }\left({ }^{\circ} \mathrm{C}\right)\end{array}$ & $\begin{array}{l}\text { Survival } \\
\text { (S) or } \\
\text { Treated } \\
\text { (T) on } \\
\text { (day) }\end{array}$ & $\begin{array}{l}\mathrm{SI}^{\mathrm{a}} \text { (SI after } \\
\text { boost/SI naïve) }\end{array}$ & $\begin{array}{l}\text { Significance of } \\
\text { SI }^{b}(P \text { values) }\end{array}$ \\
\hline \multirow[t]{4}{*}{ Erum 2580} & 208 & 10 & 41.8 & $\mathrm{~S}$ & $5.29 \pm 0.83$ & Yes $(\leq 0.003)$ \\
\hline & 209 & 11 & 41.7 & $\mathrm{~S}$ & $1.67 \pm 0.07$ & No \\
\hline & 229 & 12 & 41.7 & $\mathrm{~S}$ & $5.16 \pm 1.04$ & Yes $(\leq 0.01)$ \\
\hline & 237 & 11 & 41.7 & $\mathrm{~S}$ & $1.60 \pm 0.34$ & No \\
\hline
\end{tabular}

The average SI for the PBMC obtained from sheep immunised with 1H12 cocktail, and the individual ORFs were compared to that of the vector group. Only samples that were more than two times higher than vector and have significant $p$ values were considered as positive and are indicated in bold.

${ }^{\text {a }}$ SI values were averaged from triplicate wells.

${ }^{\mathrm{b}}$ Determined by Student's $t$-test; $p$ values of $p \leq 0.01$ were considered as significant.

\subsection{Immunological assays of sheep immunised with individual ORFs compared to the $1 \mathrm{H12}$ cocktail.}

PBMC were isolated at two time points: before first inoculation and 4 weeks after the final boost. The SI of the PBMC of each animal per group is represented in Table 5. The PBMC of two animals (sheep 62 and 120) inoculated with the 1H12 cocktail showed positive proliferation, while none of PBMC isolated from animals inoculated with empty vector showed a significant SI increase 4 weeks after the final boost. A significant increase in the SI values was also observed in sheep immunised with Erum2540 (sheep 206), Erum 2550 (sheep 130, 143 and 151), Erum 2580 (sheep 208 and 229) and Erum 2590 (sheep 183 and 184) (see Table 5 for SI and $p$-values). These results indicate that all four of the $1 \mathrm{H} 12$ gene products are expressed in the host cells and are able to stimulate recall immune responses. 


\section{Discussion}

It is well established that IFN- $\gamma$ producing T cells play an important role in protection against E. ruminantium infection [23], [24] and [25]. However, CpG motifs in bacterial DNA can also induce pseudo-protective immune responses by the induction of IFN- $\gamma$ secretion by IL-12, expressed upon binding to host Toll-like receptor 9 [26]. Research done previously in our lab has shown that DNA immunisation using pCMViUBs plasmid constructs containing four ORFs derived from E. ruminantium (Welgevonden) stock protected sheep against virulent E. ruminantium challenge [4] and [15]. To exclude the possibility that the protection was due to non-specific IFN- $\gamma$ secretion induced by $\mathrm{CpG}$ motifs in the bacterial ORF sequences, the survival of sheep immunised with the $1 \mathrm{H} 12$ cocktail was compared to that of animals immunised with two other cocktails derived from WL2AP1 and WL2HCS1, two E. ruminantium genomic clones sequenced previously [16]. As was seen in the Collins et al. [4] and [15] study, the 1H12 ORF cocktail conferred protection, but the animals immunised with the other E. ruminantium ORFs developed severe heartwater symptoms and had to be euthanased. Animals immunised with the WL2AP1 and the WL2HCS1 cocktails did survive a few days longer than the experimental control animals, which could suggest that non-specific bacterial DNA-induced IFN- $\gamma$ can delay the onset of the disease but not the final outcome. All the ORFs used to immunise the animals had similarly low GC content. Putative CpG islands with a minimum of $30 \% \mathrm{GC}$ content were identified in the $1 \mathrm{H} 12$ and the WL2AP1 ORFs but not in the WL2HCS1 ORFs. Although none of these putative CpG islands were identical to the CpG motifs previously shown to be stimulatory in sheep [27] and [28], the possibility that these motifs could induce innate immunity cannot be excluded and should be further investigated. This could be done by determining if the DNA sequences of the ORFs can induce proliferation in naive sheep PBMC. However, since CpG motifs were identified in both the 1H12 and the WL2AP1 ORFs, our challenge results suggest that the protection stimulated by the $1 \mathrm{H} 12$ cocktail depends upon specific properties of the $1 \mathrm{H} 12$ protein products.

Two of the 1H12 ORFs (Erum2590 and Erum2250) demonstrated extensive homology to ABC transporter ATP-binding/ATPase proteins. ABC transporters located in the outer membrane of Gram-positive bacteria have been shown to be effective targets for antibody 
mediated immunity against Staphylococcus aureus [29]; Enterococcus faecium [30]; Streptococcus pneumoniae [31] and Yersinia pestis [32]. Opsonising antibodies (Th1) directed against iron uptake $\mathrm{ABC}$ transporters of Streptococcus pneumoniae were shown to increase survival of mice, after exposure to a lethal dose of bacteria, from 0 to $80 \%$ via blockage of transporter function [33]. This is corroborated by the finding that Yersinia pestis mutants, deficient in the metal uptake $\mathrm{ABC}$ transporter locus, showed abridged virulence [34]. These results were obtained in Gram-positive bacteria, where the ABC transporters are located on the outer membrane and are therefore exposed to the host immune response system. $\mathrm{ABC}$ transporters of E. ruminantium are probably located on the inner membrane as in other Gram-negative bacteria and are therefore not exposed on the cell surface. Furthermore, E. ruminantium is an obligate intracellular bacterium which makes exposure to the host immune system even more complicated. Opsonising antibodies might have an effect on E. ruminantium elementary bodies which are injected into the bloodstream by infected ticks and released when an infected host cell dies, although the antibody would still have to be able to penetrate the outer membrane of the organism to exert an effect on the transporter. The protection we observed is more likely to involve either the priming of cytotoxic T cells (CTLs) via the host MHC class I system or MHC class II presentation of E. ruminantium antigen by professional antigen presenting cells (APC) and activated endothelial cells. In the immunisation strategy that we used, CTL priming was targeted by the use of an expression vector designed so that the translated protein of interest will be covalently linked to ubiquitin. Other genetic immunisation experiments done using the same pCMViUBs vector did show increased CTL responses against HIV antigens in monkeys, suggesting that targeting of the protein for MHC class I presentation does occur [35] and [36].

To determine if the protective effect was due to the combined immunological influence of all four of the ORFs or to the attributes of a single 1H12 ORF gene product, sheep were immunised with the individual 1H12 ORFs. Surprisingly, the gene products of each of the four $1 \mathrm{H} 12 \mathrm{ORFs}$ were able to induce protective immunity to a virulent $E$. ruminantium (Welgevonden) needle challenge. Expression of gene products by the recombinant $\mathrm{pCMViUBs}$ constructs, and activation of the immune response, was confirmed by recall lymphocyte proliferation assays in which only the groups immunised 
with the $1 \mathrm{H} 12$ cocktail and individual 1H12 ORFs showed antigen-specific proliferation. However, a significantly raised SI value was only detected in a few of the animals per group at a specific time point, and even then the values were in most cases only marginally higher than 2, nonetheless this does confirm that expression of the ORFs had taken place. Sheep that did not show proliferation were protected against challenge, suggesting that one can expect little correlation between protection and positive lymphocyte proliferation results in this heartwater experimental system. Similarly, Vachiery et al. [37] showed that enhanced immunity measured by IFN- $\gamma$ production in blood plasma could not be used to predict if goats immunised with a heartwater inactivated vaccine would be protected against challenge. According to these authors the lack of IFN- $\gamma$ detection in protected animals could have been due to memory $\mathrm{T}$ cells that were not circulating in the blood at the time the blood was collected. These memory $\mathrm{T}$ cells might have been detected in other immunological compartments such as the spleen and lymph nodes. Likewise, in our study the $1 \mathrm{H} 12$ specific memory $\mathrm{T}$ cells may not have been circulating when the lymphocyte proliferation assay was performed. Enhanced proliferation by PBMC might be obtained by further optimisation of the assay, including the use of recombinant $1 \mathrm{H} 12$ proteins as stimulatory antigen instead of the partially purified E. ruminantium antigen currently used. On the other hand, CTL priming was targeted in this immunisation strategy by using the pCMViUBs vector, therefore a CTL assay might give a better indication of adaptive immune activation by the in vivo expressed 1H12 proteins. Future studies will include the optimisation of ovine specific lymphocyte proliferation and CTL assays and the measurement of IFN- $\gamma$, using real time PCR and ELISPOT techniques.

Interestingly, animals that were protected showed increased temperatures of up to $42{ }^{\circ} \mathrm{C}$ (Table 4 and Table 5), but continued to act and eat normally. Fever or temperature reactions can be linked to the expression and secretion of specific pyrogenic cytokines including: IL-1, TNF- $\alpha$, IL-6 and IFN- $\gamma$ [38]. Protected animals producing IFN- $\gamma$ would also have a fever since elevated levels of IFN- $\gamma$ will induce the secretion of TNF- $\alpha$, and together these two cytokines will induce fever. On the other hand, infected endothelial cells will also induce the production of IL-1 [25] that will induce fever by up-regulating the expression of TNF- $\alpha$ [38]. It is therefore difficult to distinguish between a 
"protective" fever and one induced by infection, without measuring the individual cytokine levels produced at the time of infection.

In conclusion, we have shown that immunising ruminant hosts with a DNA vaccine containing four specific E. ruminantium ORFs, either as part of a cocktail or individually, conferred protection against a lethal E. ruminantium (Welgevonden) needle challenge. Our results suggest that this protection was a direct result of the antigenic properties of the ORF protein products, not to the induction of non-specific immune pathways. These four ORFs are promising new vaccine candidates against heartwater infection and are currently being evaluated using DNA prime-recombinant protein/modified viral boost strategies.

\section{References}

[1] A. Muller Kobold, D. Martinez, E. Camus and F. Jongejan, Distribution of heartwater in the Caribbean determined on the basis of detection of antibodies to the conserved 32kilodalton protein of Cowdria ruminantium, J Clin Microbiol 30 (1992) (7), pp. 1870 1873.

[2] A. Provost and J.D. Bezuidenhout, The historical background and global importance of heartwater, Onderstepoort J Vet Res 54 (1987) (3), pp. 165-169.

[3] G. Uilenberg, Present and future possibilities for the control of cowdriosis and anaplasmosis, Vet Q 12 (1990) (1), pp. 39-45.

[4] N.E. Collins, A. Pretorius, M. van Kleef, K.A. Brayton, M.T. Allsopp and E. Zweygarth et al., Development of improved attenuated and nucleic acid vaccines for heartwater, Dev Biol (Basel) 114 (2003), pp. 121-136.

[5] D. Martinez, J.C. Maillard, S. Coisne, C. Sheikboudou and A. Bensaid, Protection of goats against heartwater acquired by immunisation with inactivated elementary bodies of Cowdria ruminantium, Vet Immunol Immunopathol 41 (1994) (1-2), pp. 153-163.

[6] D. Martinez, J.M. Perez, C. Sheikboudou, A. Debus and A. Bensaid, Comparative efficiency of Freund's and Montanide ISA50 adjuvants for the immunisation of goats against heartwater with inactivated Cowdria ruminantium, Vet Parasitol 67 (1996) (3-4), pp. $175-184$. 
[7] P. Totté, D. Mckeever, D. Martinez and A. Bensaid, Analysis of T-cell responses in cattle immunized against heartwater by vaccination with killed elementary bodies of Cowdria ruminantium, Infect Immun 65 (1997) (1), pp. 236-241.

[8] S.M. Mahan, G.E. Smith, D. Kumbula, M.J. Burridge and A.F. Barbet, Reduction in mortality from heartwater in cattle, sheep and goats exposed to field challenge using an inactivated vaccine, Vet Parasitol 97 (2001) (4), pp. 295-308.

[9] N. Vachiéry, T. Lefrancois, I. Esteves, S. Molia, C. Sheikboudou and Y. Kandassamy et al., Optimisation of the inactivated vaccine dose against heartwater and in vitro quantification of Ehrlichia ruminantium challenge material, Vaccine 24 (2006) (22), pp. $4747-4756$.

[10] F. Jongejan, Protective immunity to heartwater (Cowdria ruminantium infection) is acquired after vaccination with in vitro-attenuated rickettsiae, Infect Immun 59 (1991) (2), pp. 729-731.

[11] E. Zweygarth, A.I. Josemans, M.F. Van Strijp, L. Lopez-Rebollar, M. Van Kleef and B.A. Allsopp, An attenuated Ehrlichia ruminantium (Welgevonden stock) vaccine protects small ruminants against virulent heartwater challenge, Vaccine 23 (2005) (14), pp. 1695-1702.

[12] A. Nyika, S.M. Mahan, M.J. Burridge, T.C. McGuire, F. Rurangirwa and A.F. Barbet, A DNA vaccine protects mice against the rickettsial agent Cowdria ruminantium, Parasite Immunol 20 (1998) (3), pp. 111-119.

[13] A. Nyika, A.F. Barbet, M.J. Burridge and S.M. Mahan, DNA vaccination with the map1 gene followed by protein boost augments protection against challenge with Cowdria ruminantium, the agent of heartwater, Vaccine 20 (2002) (7-8), pp. 1215-1225. [14] N.E. Collins, E.P. de Villiers, K.A. Brayton and B.A. Allsopp, DNA sequence of a cosmid clone of Cowdria ruminantium, Ann N Y Acad Sci 849 (1998), pp. 365-368. [15] N.E. Collins, A. Pretorius, M. van Kleef, K.A. Brayton, E. Zweygarth and B.A. Allsopp, Development of improved vaccines for heartwater, Ann N Y Acad Sci 990 (2003), pp. 474-484.

[16] A. Pretorius, N.E. Collins, H.C. Steyn and B.A. Allsopp, Sequence analysis of three Ehrlichia ruminantium LambdaGEM-11 clones, Ann N Y Acad Sci 969 (2002), pp. 155158. 
[17] K.F. Sykes and S.A. Johnston, Genetic and live vaccines mimic the antigenicity but not pathogenicity of live viruses, DNA Cell Biol 18 (1999) (7), pp. 521-531.

[18] H. Van Heerden, H.C. Steyn, M.T.E.P. Allsopp, E. Zweygarth, A.I. Josemans and B.A. Allsopp, Characterisation of the pCS20 region of different Ehrlichia ruminantium isolates, Vet Microbiol 101 (2004) (4), pp. 279-291.

[19] K.A. Brayton, G.C. Bothma, S.W. Vogel and B.A. Allsopp, Development of the OPgun $^{\mathrm{TM}}$ for bombardment of animal tissues, Onderstepoort J Vet Res 64 (1997) (2), pp. $153-156$.

[20] J.L. Du Plessis, A method for determining the Cowdria ruminantium infection rate of Amblyomma hebraeum: Effects in mice injected with tick homogenates, Onderstepoort $J$ Vet Res 52 (1985) (2), pp. 55-61.

[21] K.A. Brayton, N.E. Collins, F. van Strijp and B.A. Allsopp, Preparation of Ehrlichia ruminantium challenge material for quantifiable and reproducible challenge in mice and sheep, Vet Parasitol 112 (2003) (1-2), pp. 63-73.

[22] M. Van Kleef, N.J. Gunter, H. MacMillan, B.A. Allsopp, V. Shkap and W.C. Brown, Identification of Cowdria ruminantium antigens that stimulate proliferation of lymphocytes from cattle immunised by infection and treatment or with inactivated organisms, Infect Immun 68 (2000) (2), pp. 603-614.

[23] D.M. Mwangi, S.M. Mahan, J.K. Nyanjui, E.L.N. Taracha and D.J. McKeever, Immunisation of cattle by infection with Cowdria ruminantium elicits $\mathrm{T}$ lymphocytes that recognise autologous infected endothelial cells and monocytes, Infect Immun 66 (1998) (5), pp. 1855-1860.

[24] D.M. Mwangi, D.J. McKeever, J.K. Nyanjui, A.F. Barbet and S.M. Mahan, Immunisation of cattle against heartwater by infection with Cowdria ruminantium elicits $\mathrm{T}$ lymphocytes that recognise major antigenic proteins 1 and 2 of the agent, Vet Immunol Immunopathol 85 (2002) (1-2), pp. 23-32.

[25] P. Totté, A. Bensaid, S.M. Mahan, D. Martinez and D.J. Mckeever, Immune responses to Cowdria ruminantium infections, Parasitol Today 15 (1999) (7), pp. 286290.

[26] H. Wagner, Interactions between bacterial CpG-DNA and TRL9 bridge innate and adaptive immunity, Curr Opin Microbiol 5 (2002) (1), pp. 62-69. 
[27] Booth JS, Nichani AK, Benjamin P, Dar A, Krieg AM, Babiuk LA, et al. Innate immune responses induced by classes of $\mathrm{CpG}$ oligodeoxynucleotides in ovine lymph node and blood mononuclear cells. Vet Immunol Immunopathol, in press.

[28] G. Mutwiri, R. Pontarollo, S. Babiuk, P. Griebel, L. van Drunen and H. van den et al., Biological activity of immunostimulatory CpG DNA motifs in domestic animals, Vet Immunol Immunopathol 91 (2003) (2), pp. 89-103.

[29] J.P. Burnie, R.C. Matthews, T. Carter, E. Beaulieu, M. Donohoe and C. Chapman et al., Identification of an immunodominant $\mathrm{ABC}$ transporter in Methicillin-resistant Staphylococcus aureus infections, Infect Immun 68 (2000) (6), pp. 3200-3209. [30] J. Burnie, T. Carter, G. Rigg, S. Hodgetts, M. Donohoe and R. Matthews, Identification of $\mathrm{ABC}$ transporters in vancomycin-resistant Enterococcus faecium as potential targets for antibody therapy, FEMS Immunol Med Microbiol 33 (2002) (3), pp. 179-189.

[31] M. Jomaa, S. Terry, C. Hale, C. Jones, G. Dougan and J. Brown, Immunisation with the iron uptake $\mathrm{ABC}$ transporter proteins PiaA and PiuA prevents respiratory infection with Streptococcus pneumonia, Vaccine 24 (2006) (24), pp. 5133-5139.

[32] M. Tanabe, H.S. Atkins, D.N. Harland, S.J. Elvin, A.J. Stagg and O. Mirza et al., The $\mathrm{ABC}$ transporter protein OppA provides protection against experimental Yersinia pestis infection, Infect Immun 74 (2006) (6), pp. 3687-3691.

[33] J.S. Brown, A.D. Ogunniyi, M.C. Woodrow, D.W. Holden and J.C. Paton, Immunisation with components of two iron uptake $\mathrm{ABC}$ transporters protects mice against systemic Streptococcus pneumoniae infection, Infect Immun 69 (2001) (11), pp. 6702-6706.

[34] S.W. Bearden and R.D. Perry, The Yfe system of Yersinia pestis transports iron and manganese and is required for full virulence of plague, Mol Microbiol 32 (1999) (2), pp. 403-414.

[35] S.A. Johnston, A.M. Talaat and M.J. Mcguire, Genetic immunisation: what's in a name?, Arch Med Res 33 (2002) (4), pp. 325-329.

[36] K.F. Sykes, M.G. Lewis, B. Squires and S.A. Johnston, Evaluation of SIV library vaccines with genetic cytokines in a macaque challenge, Vaccine 20 (2002) (17-18), pp. 2382-2395. 
[37] N. Vachiery, T. Lefrancois, I. Esteves, S. Molia, C. Sheikboudou and Y.

Kandassamy et al., Optimisation of the inactivated vaccine dose against heartwater and in vitro quantification of Ehrlichia ruminantium challenge material, Vaccine 24 (2006) (22), pp. 4747-4756.

[38] P.A. Mackowiak, Concepts of fever, Arch Intern Med 158 (1998) (17), pp. 18701881.

[39] N.E. Collins, J. Liebenberg, E.P. de Villiers, K.A. Brayton, E. Louw and A.

Pretorius et al., The genome of the heartwater agent Ehrlichia ruminantium contains multiple tandem repeats of actively variable copy number, Proc Natl Acad Sci USA 102 (2005) (3), pp. 838-843.

Corresponding author at: Onderstepoort Veterinary Institute, Private Bag X5, Onderstepoort 0110, South Africa. Tel.: +27 12529 9214; fax: +27 125299417. 